\title{
The Dynamics of Rice Field Conversion Into Settlement in The District of Bandung
}

\author{
IVAN CHOFYAN \\ Program Studi Perencanaan Wilayah dan Kota, Fakultas Teknik UNISBA \\ email: vanchofyan@yahoo.co.id
}

\begin{abstract}
Bandung District as one of the rice-producing areas in West Java has a strong interest in maintaining rice field. However, the land conversion of rice field in the Bandung District continues to occur with various factors. This study aims to identify the elements that make up the structure of the phenomenon and the linkages between these elements which lead to the conversion of rice fields and recommend some policy alternatives that are useful for efforts to control the conversion of rice field. In order to achieve the stated goals, this study uses system dynamics which is one method of thinking system that could see the integral part of various aspects and structurally enable to explain the phenomenon of land conversion occurence. This study determines 4 scenarios consists of a basic scenario, rice field cropping intensity scenarios (RFCI), necessity standard of land settlement scenarios (NSLS), and food diversification scenarios (FD). The final result of this study states that the necessity standard of land settlement scenarios resulted in a decrease in the rate of land conversion is smaller and the rice stock inventory is more stable compared to other scenarios. Under these conditions, policies that support the above scenario should be established, namely the policy of land-saving settlement development and establishment of sustainable rice field.
\end{abstract}

Keywords: land conversion, rice field, land settlement, system dynamics

\section{Introduction}

Bandung District as one of the riceproducing areas in West Java has a strong interest in preserving technically-irrigated rice fields. It is due to the fact that rice field considered as scarce natural resources for its relatively fixed in amount compared to increasing needs for its uses. Rice field conversion continues to occur for several reasons. The land conversion in Bandung District had been taken place for seven years from 2004 up to 2011. In 2004, the amount of rice field area was 42,254.107 hectares and became 40,983.840 hectares in 2011 with numbers of decreased area of $1,270.267$ hectares. It means the average land decreased was 181.47 hectares or 0.44 $\%$ per year. Rice field aside, the field of corn or other commodities suffered a land decrease of 956.738 hectares with average decrease of 136.677 or $0,594 \%$ per year. On the other hand, the use of land or field for settlement or industrial area has increased in numbers. Settlement land or area increased for $2.009,379$ hectares in seven years period with average increase of 287.054 hectares or $2,01 \%$ per year. Industrial land increased for 186.165 hectares with average increase of 26.60 or $2,18 \%$ per year.

This land conversion phenomenon can be seen from many aspects, either by micro, meso or macro review. From micro review, rice field conversion occurred directly by the landowner or indirectly by other parties with prior trading rice field transaction. Meso review stated that land conversion is caused by the dynamic of urban growth, demography or economic and regional policy regarding rice field conversion. The macro review confirmed land conversion caused by policy factors, which are regulations aspect released by the central government.

Many regulations have been made to

Received: May 23, 2016, Revision: November 14, 2016, Accepted: December 30, 2016

Print ISSN: 0215-8175; Online ISSN: 2303-2499. Copyright@2016. Published by Pusat Penerbitan Universitas (P2U) LPPM Unisba Accredited by DIKTI. SK Kemendikbud, No.040/P/2014, valid 18-02-2014 until 18-02-2019 
control the conversion of agricultural land, particularly rice field. The national policies which regulate and control the agricultural land conversion, to name several of them, are Law Number 5 year 1960 on Basic Agrarian Law, Law Number 7 year 1996 on Food, Law Number 26 year 2007 on Spatial Planning, and Law Number 41 year 2009 on Protection of Agricultural Land Sustainability, followed by series of technical and implementing procedures, such as Regulation of The Minister of Agriculture Number 41/Permetan/ OT.140/9/2009 on Technical Criteria for Agricultural Area Allotment.

Regional government has also published several policies in form of law products, such as West Java Regional Regulation Number 22 year 2010 on West Java Province Spatial Planning and Regional Regulation Number 27 year 2010 on Protection of Agricultural for Food Land Sustainability. In district level, there has been local Regulation of Bandung District Number 3 year 2008 on Bandung District Spatial Planning. Various of supporting and imposing regulations have been set to perform those policies above, such as Regional Regulation on Land Use Allotment Permit followed by Regent Regulation on Implementing Procedures of Land Use Allotment Permit at district level. Regional Regulation on Coordinated Team of District Spatial was set and acted as implementator of spatial policy in each regent.

Laws and regulations related to controlling the conversion of land have been made, but the conversion still occurs. Pikiran Rakyat newspaper, dated 25 Maret 2015, quoted statement from Tisna Umaran, Head of Forestry, Plantation and Agriculture Board at Bandung District who explained that the decreasing rate of rice field for the last 10 years was 37,184 hectares to 35,682 hectares. It means there was the average of 150 hectares of rice field converted into the settlement, industrial and any others land function. The land conversion took place almost everywhere in Bandung District, with no exception for areas known as primary rice-producing such as Soreang Subdistrict, Katapang, Banjaran, Majalaya, and Rancaekek. He also urged the acceleration of regional regulation making in order to protect a minimum of 30,000 hectares of the productive-rice field to become sustainable rice field.

Rice field conversion into other uses is an inevitable phenomenon related to transformation process in land-resource allocation from one use to another. Nevertheless, since the amount of land is relatively still, the increasing demand of land for various uses would suppress the rice field to be converted into non-rice field uses and led to problems stated earlier. The first question would be, whether the rice field conversion can be controlled? The next question would be, how to conduct rice stock in Bandung District which its land has been converted? Analysis on pursuing the policy to maintain rice field could be the answer to those questions, or at least seeking policy which able to slowing down the rice field conversion in Bandung District.

In practice, policy design involves various aspects to be counted. System dynamics is one method of thinking system that could see the integral part of various aspects and structurally enable to explain the phenomenon of land conversion. Structural explanation is generative and has the ability to redesign system structure to get the conducted result as it desired (Sterman, 2000). Policy on controlling land conversion by using system dynamics model was expected to effectively prevent rice field conversion act. This study would narrow the subject study of conversion from rice field into land settlement only. This research aims to identify elements which build structured phenomenon and relation among those elements which caused rice field conversion. It is also recommended several alternative policies to control rice field conversion.

\section{The Occurrence of Rice Field}

Conversi in Academically, the term of "lahan" introduced in 1970 has a meaning of "land" in English. In the beginning, the term of lahan or land indicated "tanah". BPN (National Land Agency), for instance, always uses the word "tanah" referred to UUPA which made in 1960, for the term of lahan or land hadn't introduced yet. Lahan or land defined as biotic and physical environment related to its supporting sources toward life and wealth of human being.

Physical environment consists of relief (topography), climate, soil, and water. While biotical environment includes animals, plants, and human being (Arsyad dan Rustiadi, 2012). Barlowe (1978) stated, comprehension over land can be different depending on the context of the location where the land being used or considering the surroundings (environment) of the land. It is similar to the situation when 
we cut the diamond and find many sides of it. Barlowe (1978) continued that there are at least seven views over land, which are land viewed as space, nature, production factor, consumption goods, situation, property and capital.

In agricultural activity, land is an an important factor of production. It earns part of the harvest for its service in the production process. The payment over its service is called sewa (rent). This rent system is growing, particularly in industrial areas. It is possible for rent and land-price to be doubled if the land use would be converted from rice field into non-rice field activities. Economically, land provision is constant, while the demand for land is growing rapidly, mainly in urban area. A piece of land can be used for various needs which often unsuitable in practice and led to competitiveness among many alternatives of land uses and benefit. The interaction between land supply and demand would result in pattern of land-use to the most profitable activities. Barlowe (1978) stated that land with the highest rent tended to be mostly used by service activities, while for the consecutive lower level land is being used for industry, settlement, farming, and ended up to forest and barren land.

Land conversion can be defined as changing function of the land, either part or the whole, from its original use to others which imply negative impact (problems) to the environment and its own potential aspect (Utomo dkk, 1992). Land conversion is logical consequence of the increase of activities, population, and other development processes. In general, land conversion occurs from lower-rent land use to higher-rent ones. Forest, field, and paddy or rice field are types of land which susceptible to land conversion. A study by Firman in 2000 entitled "Rural to Urban Land Conversion in Indonesia during Boom and Bust Periods" addressed conversion of agricultural land in the suburban of the big cities in Indonesia before and at the moment of economic crisis. The result of the research showed that economic crisis in 1998 has declined the land conversion in suburban area. Aside from the declining of land conversion, the economic crisis has also created abandoned areas in the suburbans of big cities which wasted the big investments for they couldn't afford to repay the bank loan, either domestic or abroad.

Gaughan et al, 2009, conducted a research with the title of "Tourism, Forest
Conversion, and Land Transformations in the Angkor Basin, Cambodia." Land conversion in Angkor basin caused by rapid growth of tourism. It led to deforestation for $23,4 \%$ of the total forest in the area. In 2010, Pancholy et al undertook a research titled "The Impact of Biofuels on the Propensity of Land Use Conversion among Non-Industrial Private Forest Land-Owners in Florida." Background of this research was the fact that the United States imported numerous amount of oil and used $60 \%$ of that oil for transportation fuel. In the meantime, biofuel (ethanol and biodiesel) has a potential use to replace oil. In US, corn is a major raw material to produce ethanol since it is available throughout a year and relatively offers a high efficiency for conversion. Land or area allocated for planting corn is non industrial land forest owned by private companies.

In 2011, Wang dan Maclaren conducted a research entitled "Evaluation of Economic and Social Impacts of the Sloping Land Conversion Program; A Case Study in Dunhua County, China." The aim of the research was to evaluate economic and social impacts of Sloping Land Conversion Program (SLCP). It's one of the largest conservation programs in the world which targetted 14,7 million hectares of cultivating land and 17.3 million hectares of destructed land to be converted into forest or grassland. The main goal of SLCP was to decrease soil erosion by converting cultivating land at the steep slope of $25^{\circ}$ or more into forest or grassland.

Converting process of rice field area into other uses is caused by several factors. Kustiwan (1997) stated that there are three crucial factors which caused rice field conversion. They are an external factor, internal, and policy. An external factor related to dynamic growth of urban/city (physical or spatial), demographic and economy. Internal factor viewed economic and social condition of a farmer's household as land user. Policy factor was a regulation aspect issued by central or local government related to function amendment of rice field.

Conversion of cultivating land into other uses which failed to entail with employment opportunities in non-agricultural sector would cause the declining of farmer's productivity. Based on that, Jajang dkk (2013), suggested that the government and public to exercise various breakthroughs in agriculture to improve farmer's productivity. There are ways to enhance capacity of the farmer, for example; by giving series of instruction and training on 
how to manage agribusiness activities started from upstream to downstream. Most of the farmers in the rural area are traditional ones with limited and inherited knowledge. They need to be encouraged to improve their skill and productivity. Behavioral transformation in agriculture from traditional way into a modern one is expected to enhance productivity and the wealth of farmers and other agricultural workers as well.

Regulation on rice field conversion can be divided into two policies. Firstly, policy with directly or indirectly caused for occurrence of rice field conversions, such as policy on industrial activity development or housing. Generally, land allocated for that purpose is rice field and causing a conversion. It often happens that the realization which fails to pay attention to detail and consequences would lead to advanced land conversion. Secondly, policy that intended to prevent rice field conversion. Policies on controlling rice field conversion issued at national level, as well as at province and regency. Nevertheless, rice field conversion is still happening and therefore, it urgently needs comprehensive and tight policy to control the conversion.

\section{Policy Modeled Using System Dynamics}

This research uses system dynamics approach as one of the system thinking methods that view multiple aspects integrally and has the ability to explain a phenomenon structurally. A phenomenon related to structure and behavior (Tasrif, 2006). Structure constructs a phenomenon and pattern of connection among the elements which are affected by: (1) feedback (causal loop); (2) stock (level) dan flow (rate); (3) delay; and (4) nonlinearity. While behavior is transformation of variable unit in certain period of time, quantitatively or qualitatively. It can also be a note on magnitude (mass, value, numbers) of something in certain period of time (growth, decline, oscillation, stagnant and the combination of all).

According to Tasrif (2006), the appropriate problems to be modeled using system dynamic methodology are as follow: (1) naturally dynamic (change over time); and (2) its phenomenon structure contains at least one feedback structure. By using system dynamics approachment, decisions and policies that have been made and response from its surroundings would be represented in the causal-loop diagram with stock-flow model and finally simulated by computer. A phenomenon in this study is rice field conversion into other uses. Data represented in this research using system dynamics approachment are numerical, literature, and mental model (Sterman, 2000). Numerical data used is parameter constituted in physical structure, such as amount of field, land productivity, rice production, and etc. Literature data obtained either from literature study in form of books, journals, and scientific articles that have been published or policy related to rice field conversion. A mental model is a set of rules which function as a fundamental guide in decision making by executants to conduct rice field conversion (Tasrif, 2006). Data of mental model were obtained from interviews with selected respondents.

Data of literature, number, and cognition model were gathered and processed into a model design of System Dynamics by using vensim software. Vensim software can be used to make a causal impact diagram, flow diagram, and submodel (level and rate) diagram of the system studied, model development of the system, assumption test and simulator. The model that has been made is a simplification of interaction among many aspects, such as land aspect, land use, the growth of population, and growth of settlement that occurred in the real world. Model is made by computer due to its ability to apply the dynamic consequences from each interactive models (Forrester, 1995). Notation and math equation used in describing the model. Dynamic consequences emerged from interaction among simulated assumptions. The result of computer model simulation allows assumptions over rice field conversion process studied to be debated. This modelcomputer considered as a lab and place of experiment to analyze the policy that controls rice field conversion.

\section{Model behaviour and structure}

The behavior of a system or model highly depends on its structure. Structure means components that existed dan interconnected with each other. Parameter attached to each component plays an important role. In simple word, building a model structure means creating causal loop diagram which reflects the factual system. Then, behavior of each observed variables is being developed and studied based on that structure. After that, they are examined, formulated and simulated in order to acknowledge the relation between 
behavior observed variables with change of time. Models of the structure discussed are sub model of population, settlement and settlement land, rice field, and rice stock.

Population is one of the important components to be considered in this study since it keeps growing in numbers and activities, while land is available for the population relatively still. In the model, the population is considered as a level (accumulation), which can be increased and decreased due to certain processes. In this model, population increase by birth and inmigration and decrease by death and outmigration. Subsequently, sub model of the population can be seen on figure 1 .

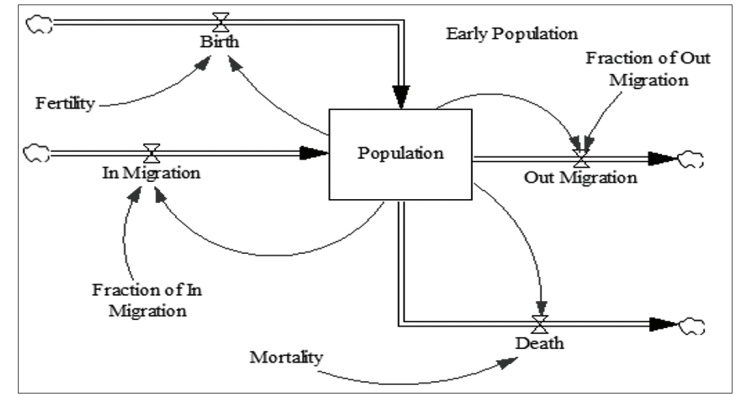

Figure 1. Sub Model of Population

Land of settlement is expanded due to the increased development of settlement unit. Settlement unit increases to fulfill the needs of houses for growing population. The possible way to solve the problem is to convert rice field into the settlement. Sub model of settlement and land/area for settlement can be seen on figure 2 .

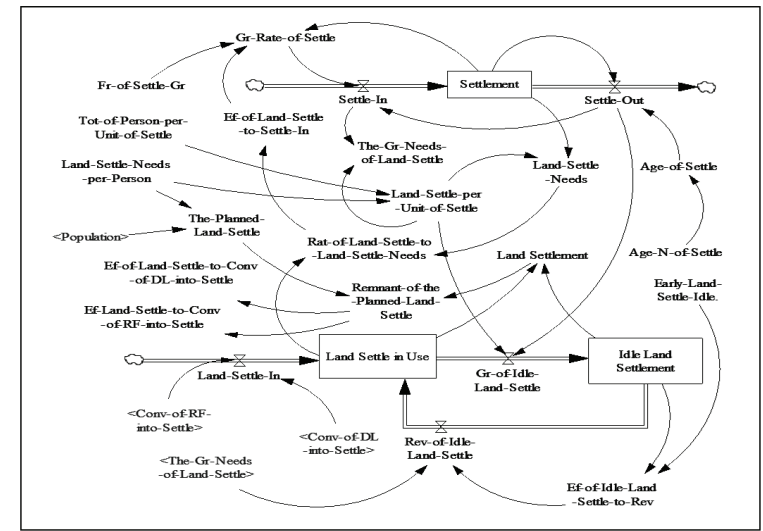

Figure 2. Sub Model of Settlement and Land Settlement

Rice field as rice producer suffered a decrease number of existence due to its conversion into settlement and industry. When the demand for settlement and industry arisen, rice field became one of possible lands to be converted into those uses. Sub model of rice field can be seen in figure 3 .

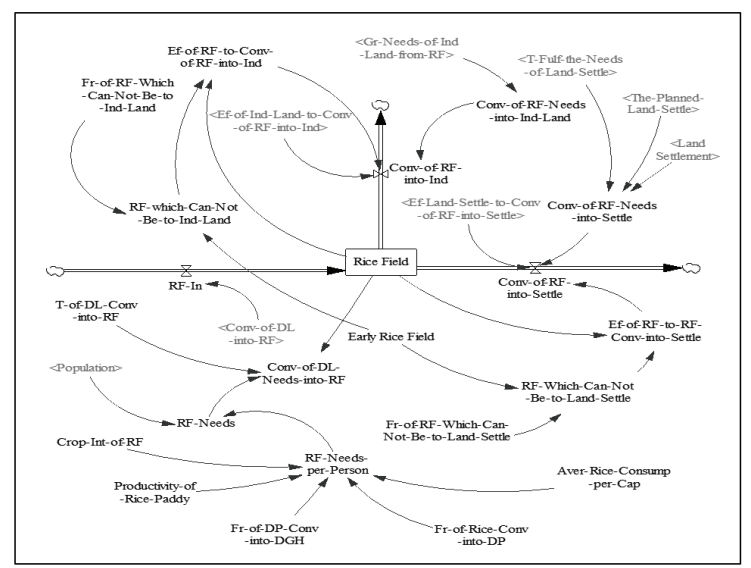

Figure 3. Sub Model of Rice field

Rice stock comes from rice field. The decrease of rice field contributes to the reduction of rice stock. Additional rice stock derived from production of rice field or dry rice cultivation, while reduction of rice stock constitutes consumption. Additional stock rice would not influence the consumption because it is relatively constant, whereas reduction of rice stock influences the consumption. Sub model of rice stock can be seen in figure 4 .

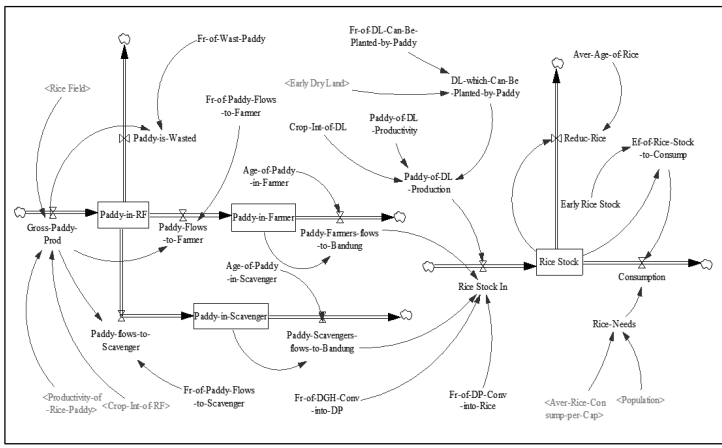

Figure 4. Sub Model of Rice Stock

A model needs to be tested before it can be used to predict the pattern of development in the future or to analyze the policy that would be made. One way to test the validity of a model is the behavior model test, which implemented by comparing model behavior to its historical data. Model validity can be seen by measuring the degree of model behavior accuracy to its historical data. Historical data which compared to model behavior in this study is data of settlement progress, as it can be seen in figure 5 .

Based on the picture above, it can be concluded that model behavior of settlement progress is considered capable of simulating its historical behavior. After regarded valid in model behavior test, the simulation would 
be continued for the next 46 years in the future. The result of simulation can be seen in figure 6.

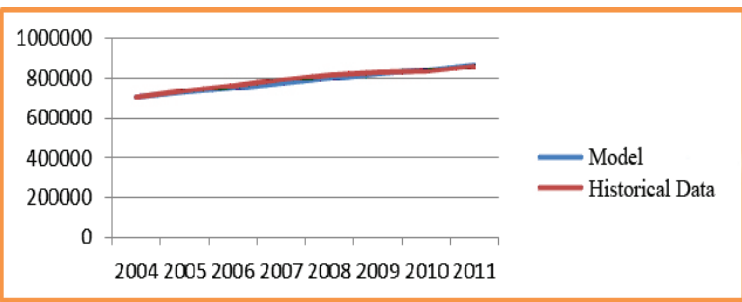

Figure 5. Model Behavior and Historical Data of Settlement

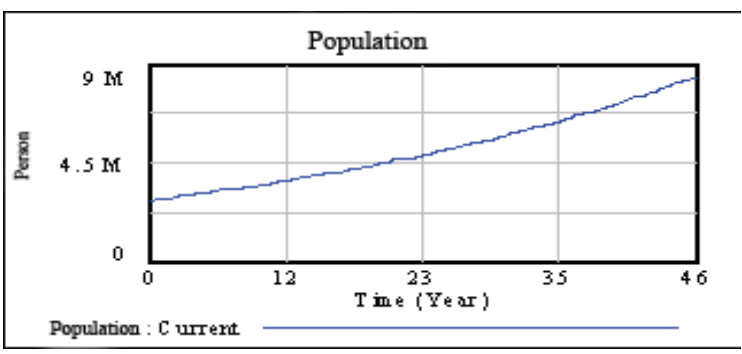

Figure 6. Population Growth on Basic Scenario.

Based on the picture above, population always tends to increase in the next 46 years to come. It is caused by the availability of the land to accommodate new population.

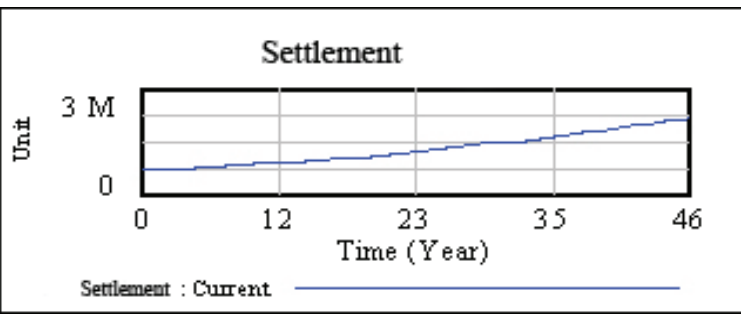

Figure 7. Settlement Growth on Basic Scenario

Growth progress of settlement keeps happening by following the patterns of growth population. Construction on settlement land also tends to grow for the next 46 years to come as shown in figure 8.

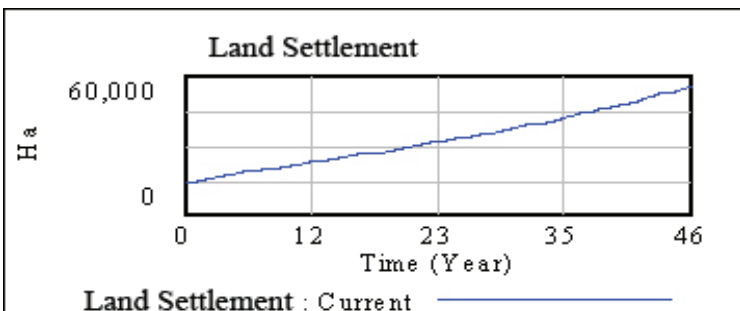

Figure 8: Growth of Land Settlement on Basic Scenario

The growth of population, settlement and settlement land contribute to the declining of rice field and rice stock as shown by figures below.

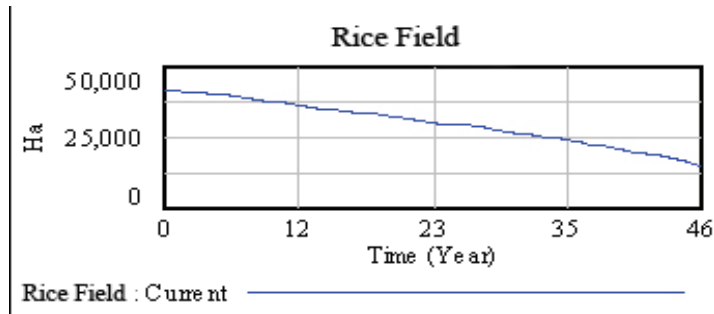

Figure 9. The Decline of Rice Field on Basic Scenario

The amount of rice field tends to decrease during that 46 years and followed by the decrease of rice production as shown by figure 10 .

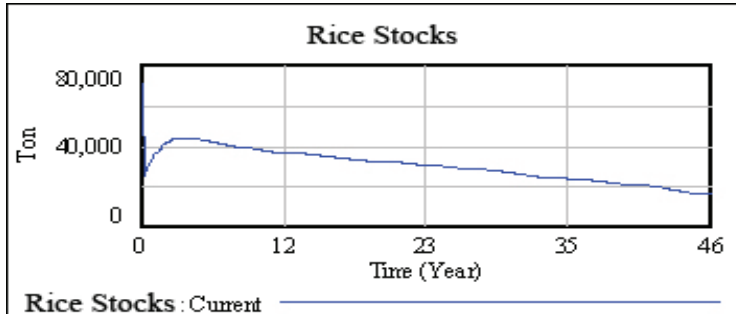

Figure10. The Decrease of Rice Stock on Basic Scenario

Enhancement on settlement growth keeps occurring and causing the decline in the amount of rice field. It means that rice field conversion will continue to happen. Conversion of rice field into settlement occurred due to the fact that land rent of settlement was higher than the land rent of rice field as explained by Barlowe (1978). Winoto (2005) stated that if land allocation completely submitted to market mechanism, economic growth would always provoke rice field conversion which already had developed infrastructure. Therefore, any attempts and efforts are needed to control rice field conversion into other uses.

The previous description explained that constructed model stated valid and therefore its behavior reflected the real condition of the studied area. This model performed as a basic scenario, which is a non-treatment model. Subsequently description would elaborate scenarios and analysis toward the behavior of the model. This constructed model would be used to predict behavior of development in the future due to policy intervention.

Policy intervention as an attempt to control the rice field conversion and to ensure the rice stock availability can be done in several ways, which are: to control the 
growth of population, to decrease people's standard needs for settlement, to decrease average rate of rice consumption per capita by food diversification, to improve the value of rice field cropping intensity and to cease the expanding of industry.

This study will determine 4 scenarios to be described, which are: (1) Basic scenario is a scenario that constructed in accordance with historical data existed at the moment. This scenario would be occurr if there is no change in policy; (2) Scenario of rice field cropping intensity (RFCI) which done by increasing intensity value of rice field cultivation from 1,75 to 2,5 . It means rice field should be cultivated 5 times in 2 years; (3) Scenario of necessity standard of land settlement (NSLS) is a scenario on how to decrease the rate of demand for settlement per person. Based on the plan, every person would live on settlement of $70 \mathrm{~m} 2$. Using this scenario needs for settlement decreased to $50 \mathrm{~m} 2$; and (4) Scenario of food diversification (FD) by reducing rice consumption. In this scenario, rice consumption reduced from 100,6 kg/ capita/year to $80 \mathrm{~kg} / \mathrm{capita} /$ year. Changing parameter within each scenario shown in table below.

The growth of settlement in Bandung District and the impact on rice field existence and rice stock have been modeled in the basic model as described earlier. In order to slow the rapid increase of rice field conversion and to keep the rice stock, several scenarios have been made to decrease rice field conversion and to establish Bandung District as a potential district of self-sufficient rice producer. Subsequently, the description would be on rice field behavior and rice stock.

The behavior of decreasing rice field until the year of 2050 occurred in all scenarios as shown in figure 11. Decreasing of rice field is different in all scenarios, where the scenario of food diversification and scenario of rice field planting intensity showed relatively the same behavior of decreasing rice field compared to the basic scenario. Those two preceded scenarios lowered the needs for rice field, therefore the needs of rice field conversion also decreased.

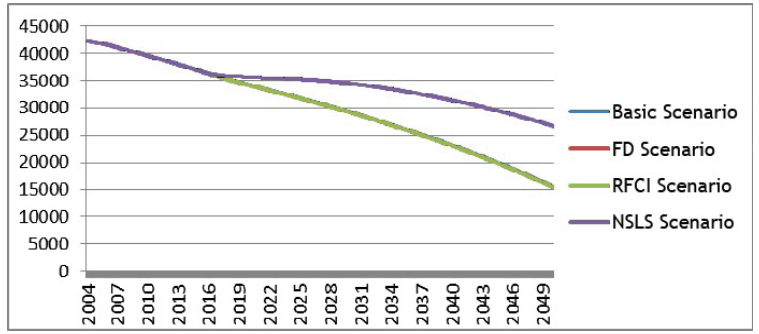

Figure 11. Behavior of Rice Field

The scenario on necessity standard of land settlement showed the slightly declining of rice field behavior. This scenario caused the amount of settlement land that has been planned were lower than that in the basic scenario. It contributed to the decreasing of needs to convert rice field into a settlement and would work on slowing down the rapid of conversion.

Additional rice stock influenced by the amount of rice field and also the intensity and productivity of cultivation, while reduction of rice stock affected by level consumption of population toward rice. The four scenarios showed different influences toward rice stock behavior as shown in figure 12 . In short term, the scenario on rice field planting intensity showed the largest rice stock, while below in consecutive are scenario on food diversification and scenario on necessity standard of land settlement.

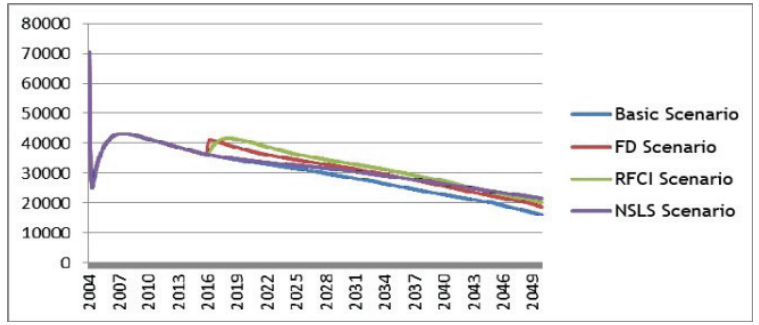

Figure 12. Behavior of Rice Stock

Table 1

Parameter in Whole Scenario

\begin{tabular}{ccccc}
\hline & $\begin{array}{c}\text { Year of Applicated } \\
\text { Policy }\end{array}$ & $\begin{array}{c}\text { Cropping } \\
\text { Intensity }\end{array}$ & $\begin{array}{c}\text { Consumption per } \\
\text { Capita }\end{array}$ & $\begin{array}{c}\text { Standard of Land } \\
\text { Settlement }\end{array}$ \\
\hline Unit & & Crop/Year & Ton/Cap/Year & $\mathrm{m}^{2} /$ Person \\
Basic Sc. & & 1,75 & 0,1006 & 0,0070 \\
FD Sc. & 2017 & 1,75 & 0,0800 & 0,0070 \\
RFCI Sc. & 2017 & 2,50 & 0,1006 & 0,0070 \\
NSLS Sc. & 2017 & 1,75 & 0,1006 & 0,0050 \\
\hline
\end{tabular}


In early years when application policy had been implemented, there were 2 scenarios that showed improvement in rice stock but had different level, which is the scenario of rice field cropping intensity and scenario on food diversification. In the following year, both scenarios showed the declining of rice stock with different level. The scenario on necessity standard of land settlement showed no improvement in the early year of the application policy, but in the long term, it indicated the stability of rice stock behavior compared to other scenarios.

\section{Conclusions}

Based on simulation and analysis of scenarios above, conclusions obtained are as follow: (1) If the development of settlement occurred accordance to the plan without any attempts of transformation or change, just be as it is, then the amount of rice field would be decreasing followed by the reduction of rice stock. Simulation of behavior with basic scenario showed that rice field has been decreasing since the beginning, while rice stock increased briefly and then decreased again with the value lower than the previous one; (2) Scenario on necessity standard of land settlement could create smaller rate of declining of rice field conversion and rice supply condition is more stable than other scenarios. Accordingly, a policy which supports this scenario should be stipulated, which is a policy on land-saving settlement development and the making of perennial rice field.

There are more factors that can be elaborated with system dynamic model in this research. For further research, suggestions below can be considered: (1) Population model is still too simple and can be expanded more. There are factors that have not been inserted yet which influence birth, death, migration in and out and also the effect of rice stock toward a population that has not been related to; and (2) In this research, the researcher has not yet inserted a factor of economic development in studied area. Economic development in certain area influences the population development, settlement, and industry. Complete description in system dynamic model would represent more about real-world behavior of land use transformation in the studied area. Therefore, simulation of policy would have the right target and similar to the real world situation.

\section{Acknowledgement}

This article is part of the writer's research entitled "Study on Controlling Rice Field Conversion Policy in Bandung District". The writer would like to thank the Minister of National Education through Directorate General of Higher Education (Dirjen Dikti) who has financed the research, and President of Islamic University who has given the opportunity to do the research.

\section{References}

Arsyad. S dan Rustiadi, E.(2012). Penyelamatan Tanah, Air, dan Lingkungan. Yayasan Pustaka Obor Indonesia. Jakarta. Badan Pusat Statistik Kabupaten Bandung. 2004 sd 2012. Kabupaten Bandung dalam Angka 2005 sd 2012.

Badan Pusat Statistik Propinsi Jawa Barat. 2005 sd 2012. Jawa Barat dalam Angka 2005 sd 2012.

Barlowe, R. (1978). Land Resorce Economics. Prentice-Hall, Inc., New Jersey.

Firman, T. (2000). Rural to Urban Land Conversion in Indonesia during Boom and Bust Periods. Land Use Policy 17. Pergamon. Elsevier Science Ltd. Page 13-20.

Forrester, J.W. (1995). Counter intuitive Behavior of Social Systems. The Messachusetts Institute of Technology (MIT). Cambridge.

Gaughan, A.E., Binford, M.W., Southworth, J. (2009). Tourism, Forest Conversion, and Land Transformations in the Angkor Basin, Cambodia. Applied Geography 29. Pergamon. Elsevier Science Ltd. Page 212-223.

Pikiran Rakyat Newspaper, Wednesday, Dated 25 March 2015, Page 6.

Jajang, A. Saefuddin, I.W. Mangku dan H. Siregar. (2013). Analisis Kemiskinan menggunakan Model Panel Spasial Statik. Jurnal Mimbar Volume 29, Nomor 2 (Desember, 2013). Hal 195-203. P2U LPPM Unisba. Bandung.

Kustiwan, I (1997). Perencanaan pembangunan di Indonesia: Bunga Rampai Perencanaan pembangunan di Indonesia. Penerbit Gramedia Widiasarana Indonesia. Jakarta.

Pancholy, N., Thomas, M.H., Solis, D., Stratis, N. (2011). The Impact of Biofuels on the Propensity of Land-Use Conversion among 
Non-Industrial Private Forest Landowners in Florida. Forest Policy and Economics 13. Pergamon. Elsevier Science Ltd

Sterman. (2000). Business Dynamic: Systems Thinking and Modelling for a Complex World. McGraw-Hill Higher Education. Boston.

Tasrif, M. (2006). Analis is Kebijakan Menggunakan Model System Dynamics. Buku 2. Program Magister Studi Pembangunan ITB. Bandung.

Utomo, M., Rifai, E., Thahar, A. (1992). Pembangunan dan Pengendalian Alih Fungsi Lahan. Universitas Lampung. Badar Lampung.

Wang, C., Maclaren, V. (2012). Evaluation of Economic and Social Impacts of the Sloping Land Conversion Program: A Case Study in Dunhua County, China. Forest Policy and Economics 14. Pergamon. Elsevier Science Ltd. Page 50-57.

Winoto, Joyo. (2005). Kebijakan Pengendalian Alih Fungsi Lahan Pertanian. Makalah (Keynote Speech) dipresentasikan dalam Seminar Penanganan Konversi Lahan dan Pencapaian Lahan Pertanian Abadi yang diselenggarakan atas Kerjasama Kantor Kementerian Koordinator Bidang Perekonomi an dengan Pusat Studi Pembangunan Pertanian dan Pedesaan (PSP3 - LPPM IPB) di Jakarta, 13 Desember 2005. 